\title{
Feeding ecology of Rhinodoras dorbignyi (Kner, 1855) (Siluriformes: Doradidae) in the Paranapanema River, SP, Brazil
}

\author{
Felipe Pontieri de Lima ${ }^{1 \%}$ \\ André Batista Nobile ${ }^{1}$ \\ Diogo Freitas-Souza ${ }^{1}$ \\ Edmir Daniel Carvalho ${ }^{1 \dagger}$ \\ Ana Paula Vidotto-Magnoni ${ }^{2}$ \\ ${ }^{1}$ Universidade Estadual Paulista, Instituto de Biociências \\ Departamento de Morfologia, Laboratório de Biologia e Ecologia de Peixes \\ Distrito de Rubião Júnior, s/n, CEP 18.618-970, Botucatu - SP, Brazil \\ ${ }^{2}$ Universidade Estadual de Londrina, Departamento de Biologia Animal e Vegetal \\ Rodovia Celso Garcia Cid, PR 445, km 380, CEP 86.057-970, Londrina - PR, Brazil \\ $\dagger$ In memoriam \\ * Autor para correspondência \\ fpl.limao@hotmail.com
}

Submetido em 27/03/2015

Aceito para publicação em 03/12/2015

\section{Resumo}

Ecologia alimentar de Rhinodoras dorbignyi (Kner, 1855) (Siluriformes: Doradidae) no rio Paranapanema, SP, Brasil. Estudos sobre caracterização da dieta de peixes representam um instrumento que permite determinar relações nas cadeias tróficas, definir hábitos alimentares e a ocupação de habitats e determinar os nichos tróficos das espécies. Para a caracterização da dieta de Rhinodoras dorbignyi, foram realizadas seis coletas bimestrais no alto rio Paranapanema, SP, durante o período de abril de 2010 a fevereiro de 2011. Dos 63 indivíduos capturados, 30 apresentaram algum conteúdo no estômago, sendo utilizados neste estudo. A dieta desta espécie foi determinada utilizando de dois métodos: (i) Índice Alimentar (\%IAi); (ii) e a interpretação gráfica da estratégia alimentar. A partir dos resultados obtidos é possível inferir que $R$. dorbignyi é uma espécie insetívora, sendo que itens de origem autóctone apresentam grande contribuição em sua dieta.

Palavras-chave: Dieta; Índice alimentar; Peixe; Recursos Alimentares; Variação sazonal

\section{Abstract}

Studies describing the diet of fish are important to determine trophic chain relationships, habitat occupation, trophic niches, and to define food habits of species. To describe the diet of Rhinodoras dorbignyi, six collections were made bimonthly in the upper Paranapanema River, SP, from April 2010 to February 2011. Of the 63 samples collected, 30 had stomach content. The diet of this species was determined using two methods: (i) alimentary index (AI\%) and (ii) graphical analysis of feeding strategy. Based on the results, $R$. dorbignyi is an insectivorous species and autochthonous items play an important role in the diet of this species.

Key words: Alimentary index; Diet; Fish; Food resources; Seasonal variation 


\section{Introduction}

Studies that describe fish diets are useful for understanding the dynamics of ecosystems and are a powerful ecological tool for conservation ecology and management. These studies allow researchers to infer about food webs, feeding habits, use of habitat and to determine trophic niches (AMUNDSEN et al., 1996), which is possible because fish diets are based on a close integration of food preferences, availability and accessibility to food.

These dimensions may vary according to environmental characteristics, time of year, growth and age of the fish, presence of intra- or interspecific competition for resources, as well as alterations in the original habitat (LOWE-McCONNELL, 1999). Hence, by knowing such relationships, it is possible to evaluate the level of interaction between species and the characteristics of the environment where the species live.

In studies about the natural feeding of fish, Agostinho et al. (2007) suggest that the main alimentary resources consumed by the ichthyofauna are of autochthonous origin, such as zooplankton, debris, fish, aquatic insects and other invertebrates. Among these, aquatic insects are considered the main resources and are represented by several large groups in the neotropical region. According Hahn and Fugi (2007), Diptera (mainly Chironomidae), Ephemeroptera and Odonata are the most significant aquatic insects in relation to fish feeding and play an important role in the metabolism of aquatic systems (PEREIRA; DE LUCA, 2003) where they are resources used in creeks, rivers and reservoirs (CALLISTO et al., 2001; LUZ-AGOSTINHO et al., 2006; PINTO; UIEDA, 2007). Ringuelet et al. (1967) and Vasconcelos et al. (2014) consider Rhinodoras dorbignyi (Kner, 1855) (Siluriformes, Doradidae) a species that can perform short distance reproductive migration. In Brazil, this species occurs in the ParanáParaguay River Basin (GRAÇA; PAVANELLI, 2007), which is severely impacted by dam. Rhinodoras dorbignyi has been reported as a rare species compared to other fish in the same basin (FAGUNDES et al., 2007). However, this species is difficult to capture and what is known about its biology and trophic ecology is limited. Due to the importance of understanding the trophic relationships of aquatic communities, the present work aimed to evaluate the diet and feeding strategies of $R$. dorbignyi in the upper Paranapanema River, in São Paulo, Brazil.

\section{Material and Methods}

The Paranapanema River (Figure 1) begins in the Paranapiacaba Sierra, in the municipality of Capão Bonito, São Paulo. It is an important left tributary of the upper Paraná River (SAMPAIO, 1944), considered oligotrophic according to the modified Carlson's trophic state index (HENRY et al., 2006) and its surrounding areas are diverse, including floodplains, agricultural regions and preserved forest fragments. The sampling area consists of a lotic environment in transition to a semi-lentic environment (HENRY, 2005; HENRY et al., 2006) and is located upstream from the Jurumirim Dam $\left(23^{\circ} 29^{\prime} 14.15^{\prime \prime} \mathrm{S}-48^{\circ} 36^{\prime} 53.53^{\prime \prime} \mathrm{W}\right)$, which is the first in a series of 11 dams located in the main channel of the Paranapanema River. This portion of Paranapanema River has a tight fitting channel, with a mean depth and width of 30 and $60 \mathrm{~m}$, respectively, low density of aquatic vegetation, two large marginal lagoons and is occupied by humans.

The ichthyofauna was evaluated based on six sample collections conducted bimonthly from April 2010 to February 2011. The fish were captured using gillnets ( 3 to $14 \mathrm{~cm}$ between opposing knots) that were installed at the end of each afternoon and retrieved early the next morning. The nets stayed out for approximately $14 \mathrm{~h}$ and the samples included specimens of Rhinodoras dorbignyi. The individuals of $R$. dorbignyi collected were dissected and the stomachs that contained content were transferred to labeled bottles filled with $4 \%$ formaline for laboratory analysis. Voucher specimens were deposited in the fish collection at the Laboratório de Biologia e Genética de Peixe (LBP 7446) at the Morphology Department of the Bioscience Institute at UNESP in Botucatu. 
FIGURE 1: Map of the Jurumirim Reservoir in the Paranapanema River, SP, highlighting the sampling area (23²9'14.15”S 48 36’53.53”W). Created by Felipe Pontieri de Lima using Quantum Gis Lisboa.

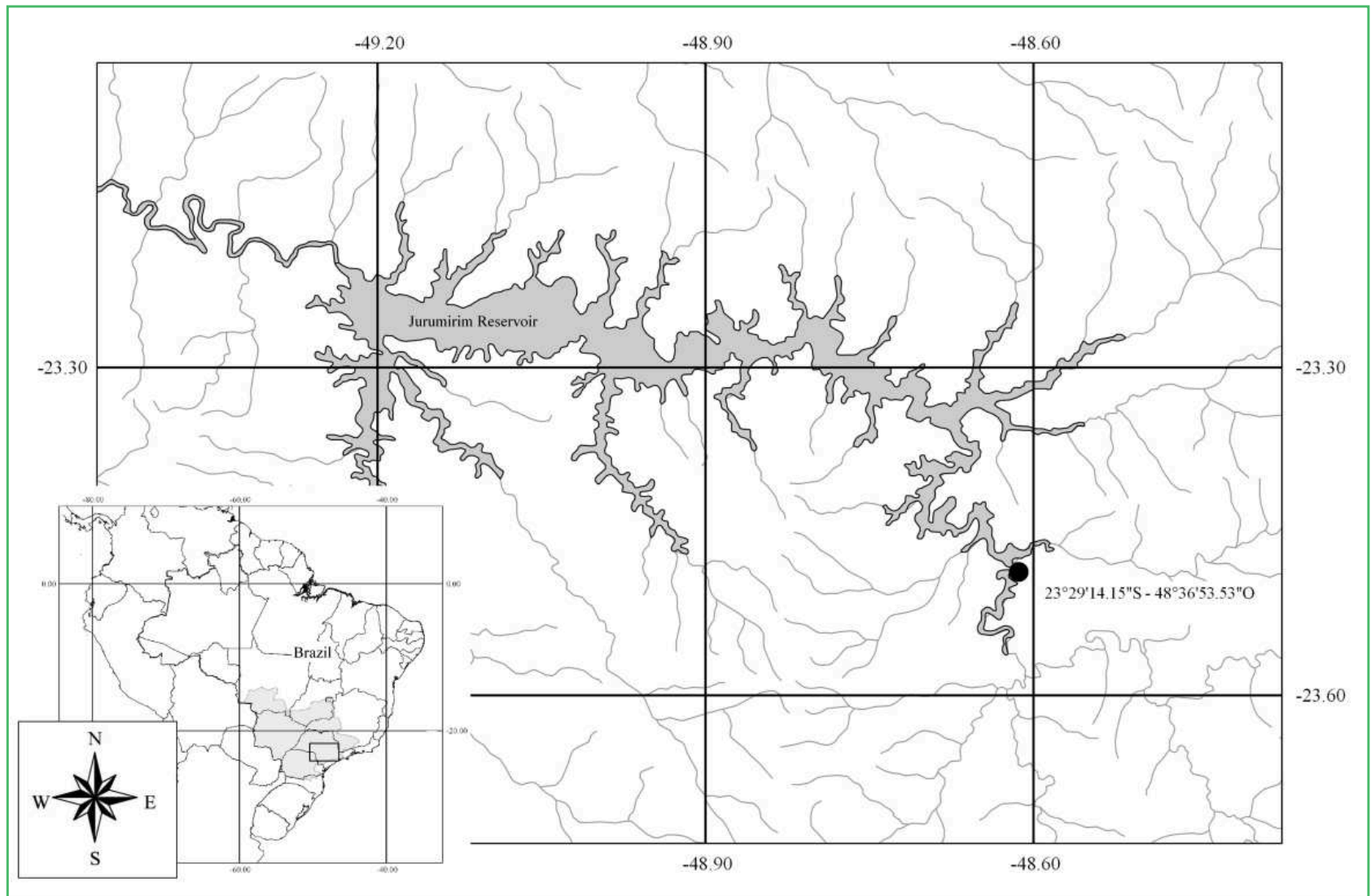

Stomach content analyses were carried out with a stereomicroscope, and items were identified to the lowest taxonomic level possible. Analyses of the diet were carried out using the frequency of occurrence and gravimetric methods combined in the alimentary index (AI\%) proposed by Kawakami and Vazzoler (1980). To evaluate differences in the alimentary items between seasons, an analysis of similarity (ANOSIM) was calculated. For this analysis, the percentage of weight of the alimentary items was used and each individual sampled was considered a replicate because the alimentary index provides only one value for the population, and does not allow for replicates. The data was transformed (square root), a resemblance matrix was generated and the ANOSIM was calculated. Furthermore, a multidimensional scale (MDS) was calculated with the resemblance matrix.
The feeding ecology and strategy of this species was evaluated by applying the graphic method elaborated by Costello (1990) and modified by Amundsen et al. (1996). This was done by plotting the specific prey abundance (Pi) and prey frequency of occurrence (FO\%). The graph provides information about important aspects of the food items, such as the following: I- dominant or rare item; II - specialist or generalist strategy and; III - individual or population contribution of food resources.

\section{Results}

Sixty-three specimens were captured (IBAMA/ ICMBio license: 15549-1) with an established standard length (SL) between 4.6 and $14.5 \mathrm{~cm}$ and biomass from 2.4 and $80.26 \mathrm{~g}$. The stomachs of 30 specimens contained some content ( 17 specimens from the dry season and 13 from the rainy season). 
The great importance of autochthonous items was registered for the diet of Rhinodoras dorbignyi, and the most consumed item was Diptera larvae $(\mathrm{AI}=74.95 \%)$ (Table 1$)$. For this region, $R$. dorbignyi is here considered a trophic specialist with a diet based on few items. Moreover, with the exception of Chironomidae and Trichoptera, which were the most consumed items, aquatic insect exoskeleton fragments, molluscs, Ephemeroptera and vegetal matter also contributed to the diet of this species.

In this study, some differences in diet composition of $R$. dorbignyi were observed. In the dry season, the diet was based mainly on Chironomidae $(\mathrm{AI}=88.42 \%)$, while in the rainy season there was an increase in the diversity of feeding items and Trichoptera and Chironomidae were the main items consumed (Table 1).

The global R statistic demonstrated there were significant differences between the items consumed during the two seasons $(\mathrm{R}=0.551, \mathrm{p}<0.01)$. The MDS corroborates this result, showing variation between the alimentary items used by the individuals between the seasons (Figure 2).

TABLE 1: Composition of the diet (AI\%) of R. dorbignyi in the upper Paranapanema River, SP.

\begin{tabular}{lcccc}
\hline \multicolumn{1}{c}{ Item } & Acronyme & \%IAi & \%IAi Dry & \%IAi Rainy \\
\hline Diptera (larvae) & Chironom. (L) & 74.95 & 88.42 & 34.22 \\
Trichoptera & Trichop. (L) & 16.68 & 4.16 & 35.71 \\
Ephemeroptera & Ephem. (L) & 1.56 & 6.02 & - \\
Odonata larvae & Odonata (L) & 0.06 & - & 0.36 \\
Hemiptera & Aqu. Hemp. & $*$ & - & $*$ \\
Aquatic insect exoskeleton fragments & AIF & 2.46 & - & 15.42 \\
Mollusks & Mollusks & 2.30 & 0.65 & 7.68 \\
Terrestrial insect exoskeleton fragments & TIF & 0.06 & - & 0.38 \\
Vegetal matter & Vegetal matter & 1.13 & 0.04 & 4.87 \\
Debris/Sediment & Det & 0.81 & 0.72 & 1.36 \\
\hline
\end{tabular}

$\mathrm{L}=$ larvae; * values lower than 0.0001 ; Boldface items are of allochthonous origin.

FIGURE 2: Multidimensional scale (MDS) of the percentage of weight of alimentary items of Rhinodoras dorbignyi caught during different seasons in the Paranapanema River, São Paulo State, Brazil.

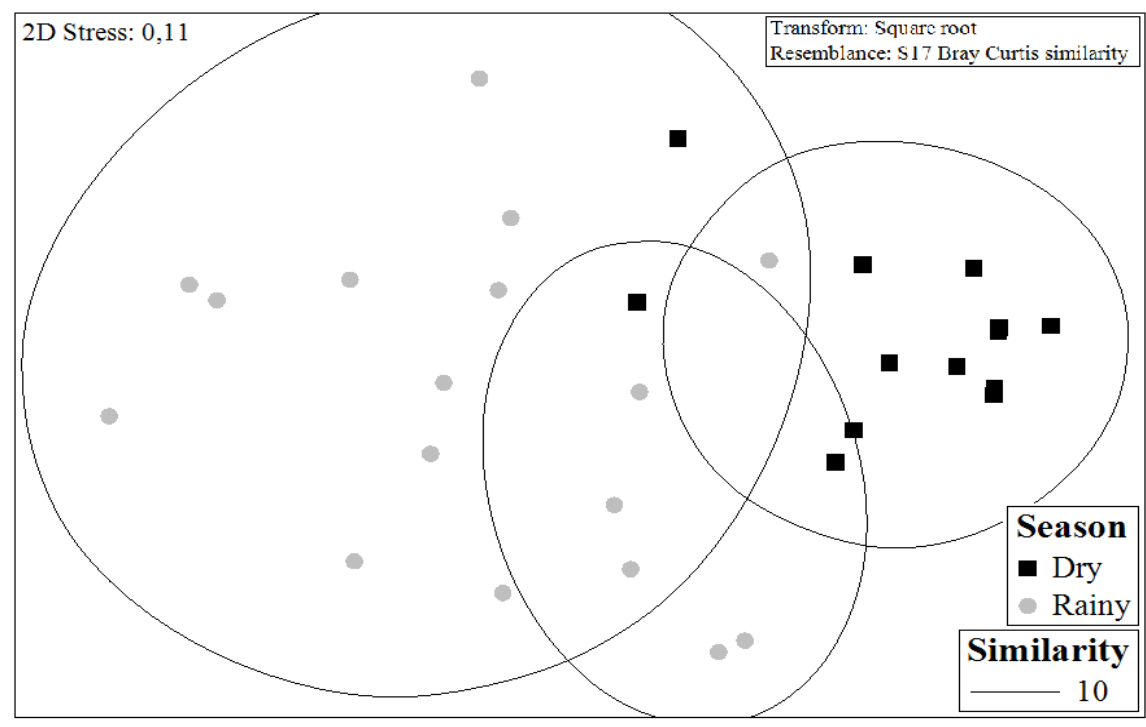


Similar to what was observed in the alimentary index analysis, the feeding strategy of this species shows that Chironomidae and Trichoptera are the dominant items in the diet of $R$. dorbignyi. The model also shows that most items are rare (and therefore plotted in the lower left portion of the graph). Debris/ sediment, Ephemeroptera and vegetal matter are located in the upper left corner of the graph, which shows these items are used in great quantities; nonetheless, they are consumed by few individuals of the population and represent intra-individual components in the exploration of the niche (Figure 3).

\section{Discussion}

Insect larvae are the food resource most consumed by fish and represent an important nutritional source for fish communities (WINEMILLER; LESLIE 1992; HARTZ et al., 2000). The results of this study corroborate the data found in the literature because $R$. dorbignyi from the Paranapanema River eats insects in the larval phase. An insectivorous habit is found in various fish species (VIDOTTO-MAGNONI; CARVALHO, 2009). It is also reported for $R$. dorbignyi in other environments, such as the Corumbá Reservoir (Paraná River Basin) and the Ibicuí River (Uruguay River Basin) (LUZAGOSTINHO et al., 2006; FAGUNDES et al., 2007).

In the Ibicuí River, Fagundes et al. (2007) states that the main food resource of $R$. dorbignyi is Ephemeroptera. However, in the Paranapanema River, the species feeds mainly on Chironomidae. Santos and Henry (2001) report the abundance of insect larvae from this family in this river, which justifies the difference found. Reinforcing this possibility, studies related to trophic ecology have revealed considerable feeding versatility for most teleostean fish (HAHN; FUGI, 2007). This is a particularly significant aspect for tropical fish species, which may change food resources as soon as there are changes in the relative abundance of the food resource in use (GOULDING, 1980; WOOTON, 1990; GERKING, 1994; HAHN et al., 1997; AGOSTINHO; JÚLIOJÚNIOR, 1999). Agostinho et al. (1997) corroborate the trophic flexibility of fish species. The authors suggest that the diet of fish may vary due to different factors, such as the difference in the availability of the alimentary resources found in a certain habitat or season of the year, as observed here for $R$. dorbignyi.

Hence, the seasonal variation found in the diet of the species is possibly associated to the availability of resources during different hydrologic periods. Davanso

FIGURE 3: Rhinodoras dorbignyi feeding strategy in the Paranapanema River, São Paulo State, Brazil.

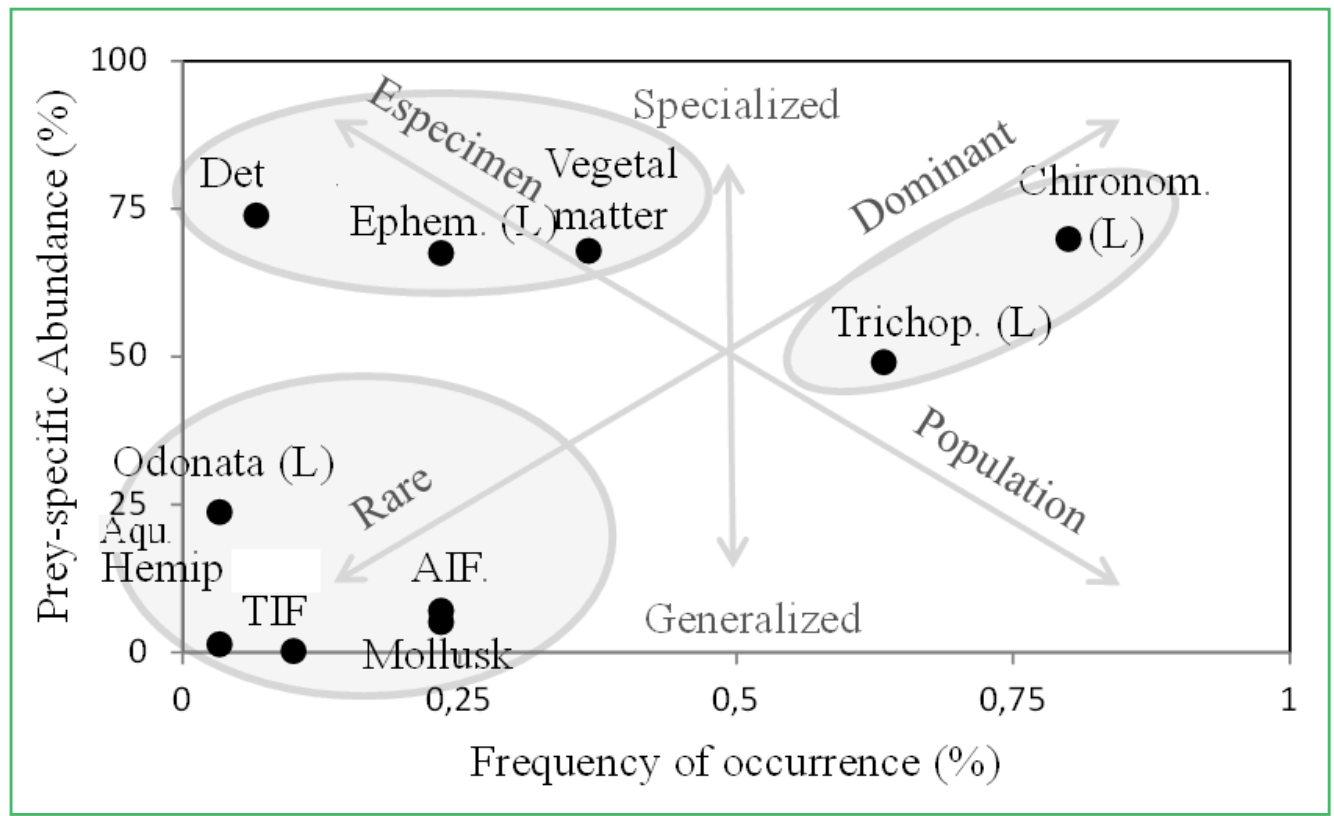


and Henry (2006) observed that during the dry season the density of Chironomidae per square meter in a lagoon located next to where the samples were collected was relatively greater than during the rainy season. The higher density of prey (Chironomidae) is likely to cause this resource to be a target that requires less energy during capture (theory of optimal foraging, GRIFFITHS, 1975), which justifies the variation in the use expressed by the species during the studied periods.

Dias et al. (2005) states that the determination of feeding habits of a species changes according to the dynamic of the alimentary resources. Thus, the occurrence of a generalist or specialist species is favored in certain habitats due to the characteristics of the resources available, as observed in tropical fish species and $R$. dorbignyi in the present study. However, even though they use different resources, the trophic guild of this species is the same when evaluated during different seasons of the year and even in different environments, such as the Ibicuí River (FAGUNDES et al., 2007). Despite presenting seasonal (dry and rainy seasons) and spatial (Ibicuí River and Paranapanema River) variation in its diet, $R$. dorbigniy is an insectivorous species with a diet based mostly on aquatic insect larvae.

The Paranapenama River is one of the main tributaries of the Jurumirim Reservoir. It plays an important ecological role because there are no dams upstream from this reservoir, which increases the variety of habitats and helps maintain species richness of fish. Brandão et al. (2009) studied the fish fauna of a reservoir downstream from Jurumirim and considered $R$. dorbignyi rare and usually found in lotic environments, which is similar to the results observed in the present study. Thus, the knowledge of feeding strategies and the diet of $R$. dorbiginyi in these habitats can be used as ecological tools that can help in the management and conservation of this species and the entire fish fauna.

\section{References}

AgOstinHO, A. A.; GOMES, L. C.; PELICICE, F. M. Ecologia e manejo de recursos pesqueiros em reservatórios do Brasil. Maringá: EDUEM, 2007. 501 p.

AGOSTINHO, A. A.; HAHAN, N. S.; GOMES, L. C.; BINI, L. M. Estrutura trófica. In: VAZZOLER, A. E. A. M.; AGOSTINHO;
A. A.; HAHN, N. S. (Ed.). A planície de inundação do alto rio Paraná: aspectos físicos, biológicos e socioeconômicos. Maringá: EDUEM, 1997. p. 209-228.

AGOSTINHO, A. A.; JÚLIO-JÚNIOR, H. F. Peixes da bacia do alto rio Paraná. In: LOWE-McCONNEL, R. H. (Ed.). Estudos ecológicos de comunidade de peixes tropicais. São Paulo: EDUSP, 1999. p. 374-400.

AMUNDSEN, P. A.; GABLER, H. M.; STALDVIK, F. J. A new approach to graphical analysis of feeding strategy from stomach contents data modification of the Costello (1990) method. Journal of Fish Biology, Hoboken, v. 48, p. 607-614, 1996.

BRANDÃO, H.; VIDOTTO-MAGNONI, A. P.; RAMOS, I. P.; CARVALHO, E. D. Assessment of the ichthyofauna in stretches under the influence of Salto Grande Reservoir (Middle Paranapanema River, SP/PR, Brazil). Acta Limnologica Brasiliensia, Botucatu, v. 21, n. 4, p. 451-463, 2009.

CALLISTO, M.; MORETTI, M.; GOULART, M. Macrointertebrados bentônicos como ferramenta para analisar a saúde de riachos. Revista Brasileira de Recursos Hídricos, Belo Horizonte, v. 6, n. 1, p. 71 82,2001

COSTELLO, M. J. Predator feeding strategy and prey importance: a new graphical analysis. Journal of Fish Biology, Hoboken, v. 36, p. 261-263, 1990 .

DAVANSO, R. C. S.; HENRY, R. A. Biodiversidade bentônica após período prolongado de seca em lagoa marginal ao rio Paranapanema na zona de sua desembocadura na Represa de Jurumirim (São Paulo). Acta Scientiarium Biological Sciences, Maringá, v. 28, n. 4, p. 347-357, 2006.

DIAS, A. C. M. I.; BRANCO, C. W. C.; LOPES, V. G. Estudo da dieta natural de peixes no reservatório de Ribeirão das Lajes, Rio de Janeiro, Brasil. Acta Scientiarium Biological Sciences, Maringá, v. 27, n. 4, p. 355-364, 2005.

FAGUNDES, C. K.; BEHR, E. R.; KOTZIAN, C. B. Alimentação de Rhinodoras dorbignyi (Kröyer, 1855) (Siluriformes: Doradidae) no rio Ibicuí, Rio Grande do Sul, Brasil. Acta Scientiarium Biological Sciences, Maringá, v. 27, n. 4, p. 365-369, 2007.

GERKING, S. D. Feeding ecology of fishes. San Diego: Academic Press, 1994. $416 \mathrm{p}$.

GOULDING, M. The fishes and the forest: explorations in amazon natural history. Berkeley: University of California Press, 1980. $280 \mathrm{p}$

GRAÇA, W. J.; PAVANELli, C. S. Peixes da planície de inundação do Alto Rio Paraná e áreas adjacentes. Maringá: EDUEM, 2007. 168 p.

GRIFFITHS, D. Prey availability and food of predators. Ecology, New York, v. 56, p. 1209-1214, 1975.

HAHN, N. S.; ADRIAN, I. F.; FUGI, R.; ALMEIDA, V. L. L. Ecologia trófica. In: VAZZOLER, A. E. A. M.; AGOSTINHO; A. A.; HAHN, N. S. (Ed.). A planície de inundação do alto rio Paraná: aspectos físicos, biológicos e socioeconômicos. Maringá: EDUEM, 1997. p. 209-228.

HAHN, N. S.; FUGI, R. Alimentação de peixes em reservatórios brasileiros: alterações e consequências nos estágios iniciais do represamento. Oecologia Brasiliensis, Rio de Janeiro, v. 11, n. 4, p. 469-480, 2007.

HARTZ, S. M.; VERANI, J. R.; BARBIERI, G. Partilha de recursos entre as espécies de ciclídeos (Teleostei, Perciformes) em uma 
lagoa no litoral norte do Rio Grande do Sul, Brasil. Biociências, Porto Alegre, v. 8, n. 1, p. 33-58, 2000.

HENRY, R. The connectivity of Paranapanema River with two lateral lakes in its mouth zone into Jurumirim Reservoir. Acta Limnologica Brasiliensia, Botucatu, v. 17, n. 1, p. 57-69, 2005.

HENRY, R.; PANARELLI, E. A.; CASANOVA, S. M. C.; SIUBERTO, M. R.; AFONSO, A. A. de O. Interações hidrológicas entre Lagoas marginais e o rio Paranapanema na zona de sua desembocadura na represa de Jurumirim. In: NOGUEIRA, M. G.; HENRY, R.; JORCIN, A. (Ed.). Ecologia de reservatórios: impactos potenciais, ações de manejo e sistema em cascata. 2. ed. São Carlos: Editora RiMA, 2006. p. 57-82.

KAWAKAMI, E.; VAZZOLER, G. Método gráfico e estimativa de índice alimentar aplicado no estudo de alimentação de peixes. Boletim do Instituto Oceanográfico, São Paulo, v. 29, n. 2, p. $205-$ 207, 1980.

LOWE-McCONNELL, R. H. Estudos ecológicos de comunidades de peixes tropicais. São Paulo: Editora da USP, 1999. 534 p.

LUZ-AGOSTINHO, K. D. G.; BINI, M.; FUGI, R.; AGOSTINHO, A. A.; JÚLIO JR., H. Food spectrum and trophic structure of the ichthyofauna of Corumbá Reservoir, Paraná River basin, Brazil. Neotropical Ichthyology, Porto Alegre, v. 4, n. 1, p. 61-68, 2006.

PEREIRA, D.; DE LUCA, S. J. Benthic macroinvertebrates and the quality of the hydric resources in Maratá Creek basin (Rio Grande do Sul, Brazil). Acta Limnologica Brasiliensia, Botucatu, v. 15, n. 2, p. 57-68, 2003.
PINTO, T. L. F.; UIEDA, V. S. Aquatic insects selected as food for fishes of a tropical stream: are there spatial and seasonal differences in their selectivity? Acta Limnologica Brasiliensia, Botucatu, v. 19, n. 1, p. 67-78, 2007.

RINGUELET, R. A.; ARÁMBURU, R. H.; ARÁMBURU, A. A. Los peces argentinos de agua dulce. La Plata: Comision de Investigacion Científica, 1967. 602 p.

SAMPAIO, T. Relatório sobre os estudos efetuados nos rios Itapetininga e Paranapanema. Revista do Instituto Geográfico e Geológico, São Paulo, v. 2, n. 3, p. 30-81, 1944.

SANTOS, C. M.; HENRY, R. Composição, distribuição e abundância de Chironomidae (Diptera, Insecta) na Represa de Jurumirim (rio Paranapanama-SP). Acta Limnologica Brasiliensia, Botucatu, v. 13, n. 2, p. 99-115, 2001.

VASCONCELOS, L. P.; ALVES, D. C.; GOMES, L. C. Fish reproductive guilds downstream of dams. Journal of Fish Biology, Malden, v. 85, p. 1489-1506, 2014.

VIDOTTO-MAGNONI, A. P.; CARVALHO, E. D. Aquatic insects as the main food resource of fish the community in a Neotropical reservoir. Neotropical Ichthyology, Porto Alegre, v. 7, n. 4, p. 701708, 2009.

WINEMILLER, K. O.; LESLIE, M. A. Fish assemblages across a complex tropical freshwater/marine ecotone. Environmental Biology of Fishes, Dordrecht, v. 34, p. 29-50, 1992.

WOOTON, R. J. Ecology of teleost fishes. London: Chapman \& Hall, 1990. 404 p. 